The University of Maine

\title{
DigitalCommons@UMaine
}

Marine Sciences Faculty Scholarship

School of Marine Sciences

2-1-1998

\section{On the Identity of Spencebatea Abyssicola (Cumacea), with Additional Observations on the Genera Allied to Procampylaspis}

Les Watling

University of Maine - Main, watling@maine.edu

Follow this and additional works at: https://digitalcommons.library.umaine.edu/sms_facpub

\section{Repository Citation}

Watling, Les, "On the Identity of Spencebatea Abyssicola (Cumacea), with Additional Observations on the Genera Allied to Procampylaspis" (1998). Marine Sciences Faculty Scholarship. 84.

https://digitalcommons.library.umaine.edu/sms_facpub/84 


\title{
ON THE IDENTITY OF SPENCEBATEA ABYSSICOLA (CUMACEA), WITH ADDITIONAL OBSERVATIONS ON THE GENERA ALLIED TO PROCAMPYLASPIS
}

\author{
Les Watling
}

A B S T R A C T

In 1879 Norman described Spencebatea abyssicola, new genus, new species, on the basis of a single specimen from a deep-sea site off Ireland. The species was transferred to the genus Cumella by Stebbing in 1913, where it has remained. A reexamination of the specimen indicated that it belongs to the genus Procampylaspis, since it possesses the recurved, tooth-bearing dactyl on maxilliped 2 which characterizes the genus. Seven other genera also exhibit modified dactyls on maxilliped 2, and, in addition, have styliform mandible molars, thus forming a coherent group within the family Nannastacidae.

Norman (1879) described the new genus, new species, Spencebatea abyssicola, from a single specimen dredged in 1869 by the Porcupine west of Donegal Bay [at Station 19, with coordinates $54^{\circ} 53^{\prime} \mathrm{N}, 10^{\circ} 56^{\prime} \mathrm{W}$, and water depth 1,360 fathoms $(2,487 \mathrm{~m})]$. The specimen was a subadult male and was described relatively completely (for the time), but was not illustrated. Nevertheless, Norman recognized that his species did not fit with any previously described genera. He gave as the diagnosis for this genus the following:

"Characters of male. - General aspect that of Diastylis. Five segments of cephalothorax exposed behind the carapace. All feet, except the last, palpigerous. No feet on the pleon. Telson rudimentary (as in Eudorella). Uropods with both branches two-jointed. Female unknown."

This diagnosis served to distinguish his new genus from all other genera existing at the time, with the possible exception of Cumella, perhaps explaining why Stebbing (1913) moved the species to that genus with no comment (and, apparently, without examining the specimen). In a later revision of the genus Cumella, Watling (1991) failed to list the species.

Bonnier (1896) described the genus Procampylaspis for two new species, $P$. armata and $P$. echinata. Both species were taken in $950 \mathrm{~m}$ at the Caudan Station 13 in the Gulf of Gascogne. Bonnier noted the principal distinguishing feature of his new genus to be "la structure si particulière du dactylopodite du deuxième maxillipède (p. 544)." The ter- minal article of this appendage bears strongly projecting and recurved teeth on its concave margin, which are now known to be highly characteristic of all species in this genus. In fact, all genera in the Campylaspis-Procampylaspis group have the dactyl of the second maxilliped modified in some way.

A reexamination of Norman's specimen (BMNH No. 1911.11.8:6023) showed that it clearly belongs in the genus Procampylaspis. This paper deals first with the redescription of Norman's specimen in the genus Procampylaspis, since it appears not to have been examined since its original discovery, and second, with a comparison of the closely allied genera.

\section{Procampylaspis Bonnier, 1896}

Spencebatea Norman, 1879, nomen oblitum

Diagnosis.-Carapace elevated posteriorly, anterolateral (antennal) angle rudimentary to obtuse. Eye lobe rudimentary. Mandible molar styliform. Maxilliped 2 with 7 articles; carpus and propodus in line (not angled); propodus distal spine-seta absent; dactyl with 5 ventral teeth or spine setae, distalmost recurved.

\section{Figs. 1, 2 \\ Spencebatea abyssicola Norman, 1879. \\ Cumella abyssicola Stebbing, 1913. \\ Procampylaspis inermis Jones, 1984.}

Procampylaspis abyssicola (Norman, 1879)

Description (Modified from Norman).-Subadult male and female, length 3-3.5 mm. Carapace smooth, with some scattered setae, about twice as long as deep; pseudorostrum about one-seventh length of carapace; eye 


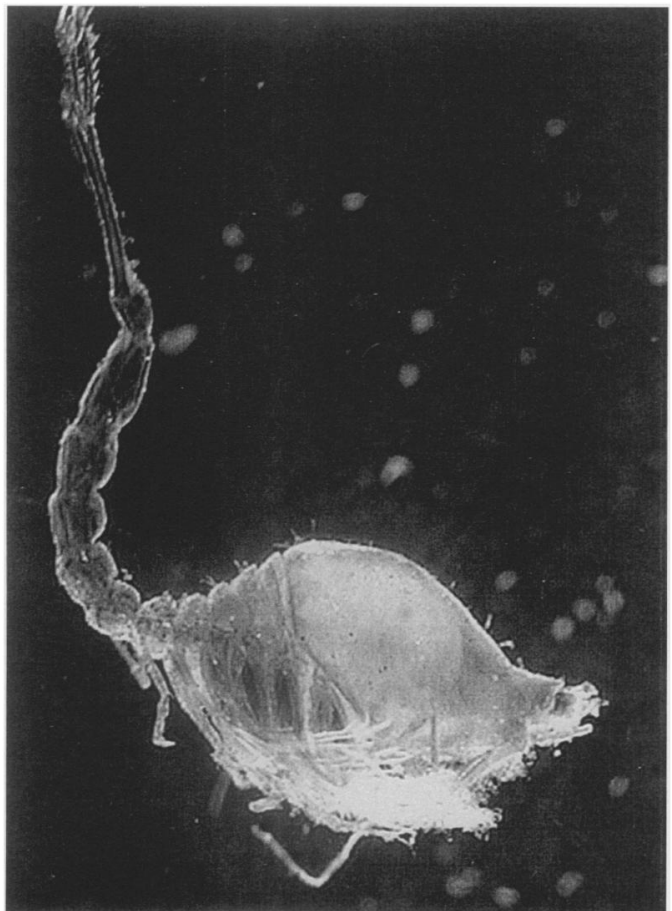

Fig. 1. Print from video image of holotype of Spencebatea abyssicola.

lobe small; anterolateral angle weak. Pereionites 1 and 2 with projections. Maxilliped 2 merus with 2 long plumose setae, 1 midfacial and 1 mediodistal; carpus with 1 simple plumose seta; propodus with short plumose seta distally; dactyl with third tooth longest, fourth tooth reduced and bearing small seta. Pereiopod 2 article 5 with 2 distal spinelike setae. Uropod peduncle elongate, with 8 setae along medial margin; endopod with 6 medial setae and 2 terminal spinelike setae, one of which about one-half length of article; exopod with 2 terminal spinelike setae, longest equal in length to distal article.

Remarks.-The primary problem with resolving taxonomic difficulties of this kind has to do with the fact that descriptions often do not include the details necessary to determine whether two taxa are synonymous. In the present case, Norman's verbal description, while fine for the time, did not have with it illustrations comparable to those being produced by other authors. Therefore, details that ordinarily would have been in the drawings were not available to colleagues, such as Stebbing, who were taking a larger, synthetic, look at the group. On the other hand, the more modern descriptions by Jones (and others, including myself), while encompassing more of the animal, assume a degree of homogeneity within a genus, a certain level of detail is often omitted. As a consequence, the true identity of Norman's species could not be resolved until his specimen was reexamined and compared with specimens of other deep North Atlantic species, chiefly those described by Jones (1984).

Norman failed to note that his specimen was a subadult male (the second antenna, while being present, is not fully developed, as evidenced by its lack of setae) and that it bore projections on pereionites 1 and 2 . He did not describe maxilliped 2 and therefore missed the significance of this appendage which was later seen by Bonnier. The description of $P$. inermis by Jones (1984) includes the statement "pereon and pleon somites without spines or other projections apart from a few setae." An examination of the type series (BMNH Numbers 1982:338:1 and 1982:340:10; see Jones, 1984, for exact locality data) showed that juvenile and subadult females of $P$. inermis have middorsal projections on the first and second pereionites, although in older females the lappets are closely pressed against the body. In Norman's specimen the lappets are small, approximating those of the females. Other similarities between Norman's specimen and those of $P$. inermis include: (1) the shape and design of the teeth of the maxilliped 2 dactyl (see Fig. 2); (2) the presence of a large plumose seta on the second maxilliped meral face; (3) the details of the setation and the presence of a meral hyaline frill on maxilliped 3 ; and (4) the details of the setation on the peduncle and inner ramus of the uropods in the subadult male.

As noted above, Stebbing moved Norman's species into the genus Cumella, presumably based entirely on Norman's written description. He had perhaps been influenced by Sars (1887), who suggested that the genus Spencebatea belonged in the Cumellidae, which to that time contained only the genera Cumella and Nannastacus. If Stebbing had examined Norman's specimen, he would have seen immediately that the genus Procampylaspis of Bonnier was, in fact, synonymous with Norman's Spencebatea. Unfortunately, this fact has gone unnoticed for all these years. Now, according to the International Code of Zoo- 


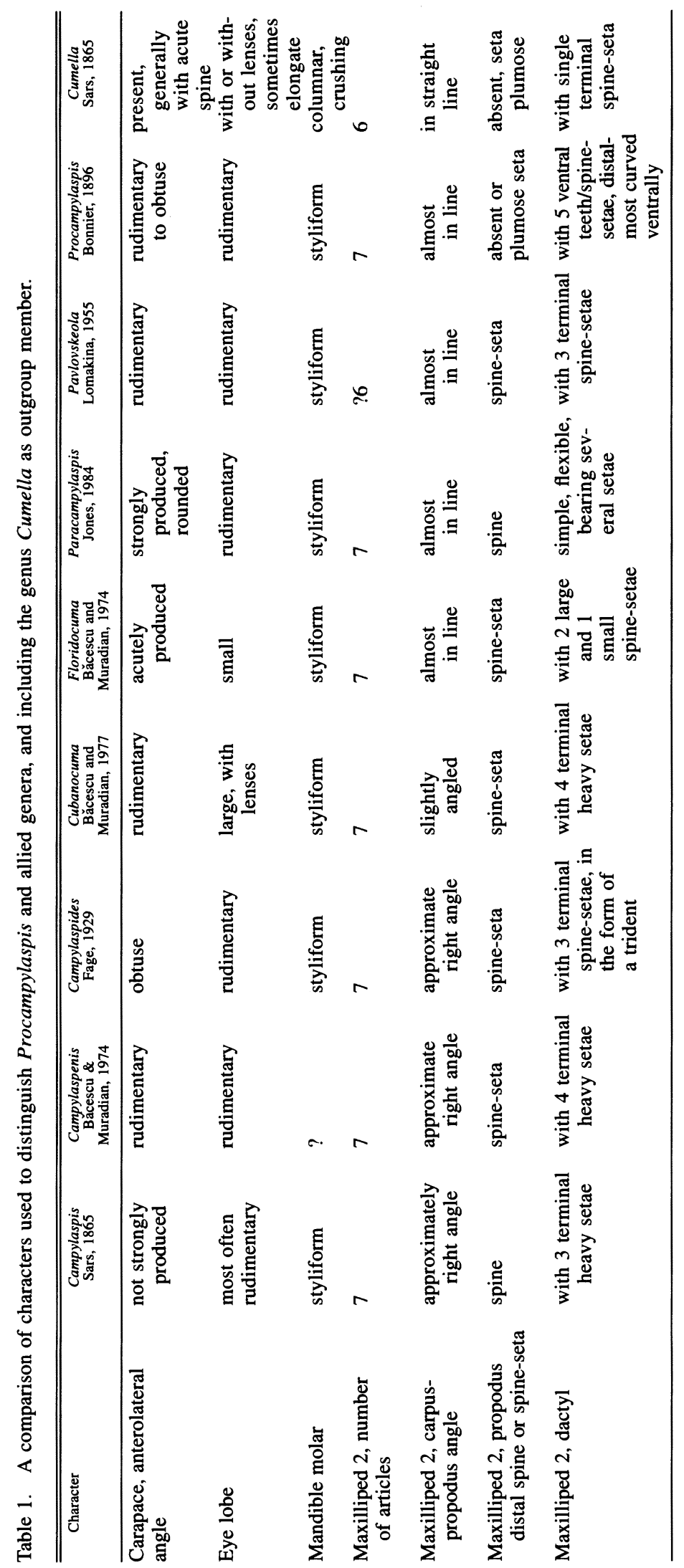



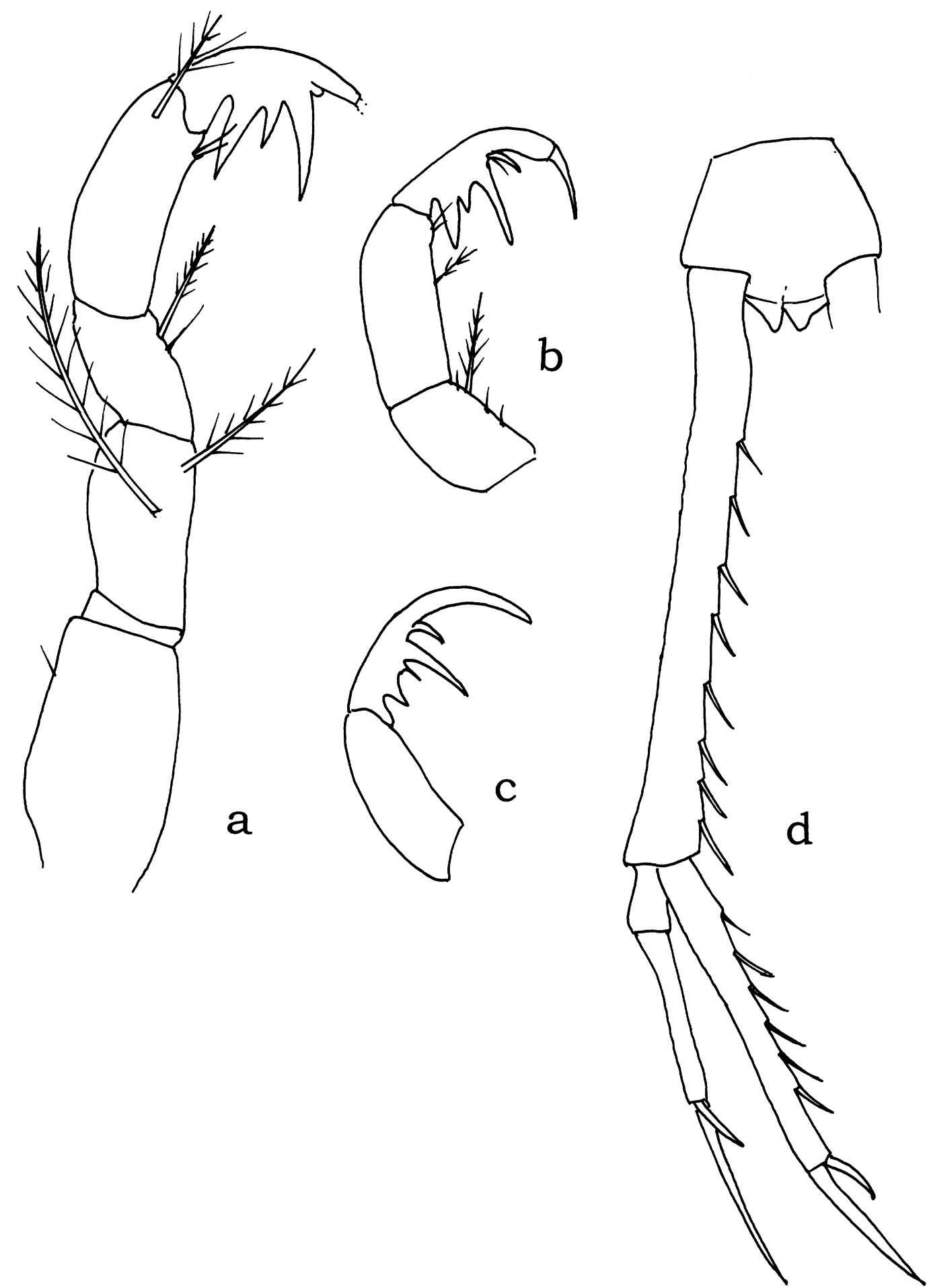

Fig. 2. a, maxilliped 2 of type specimen of Spencebatea abyssicola; b, propodus and dactyl of maxilliped 2 from a paratype subadult female Procampylaspis inermis Jones; c, propodus and dactyl of maxilliped 2 from a paratype mature male $P$. inermis Jones; d, uropod from type specimen of $S$. abyssicola. 
logical Nomenclature, Article 23b, the genus Spencebatea should be submerged in the interests of nomenclatural stability.

\section{COMPARISON OF THE GENERA AlLIED TO PROCAMPYLASPIS}

Within the family Nannastacidae there is a group of seven genera, all of which possess a second maxilliped with the dactyl modified in some way-usually bearing teeth in various arrangements-and a styliform mandible. These genera have several similarities and form a more or less coherent grouping. In Table 1 the important mouth appendage characters are given for this group of genera along with the same features for the genus Cumella, which typifies the remaining 12 nannastacid genera. It should be noted that the table includes the genus Floridocuma Bacescu and Muradian, which had been incorporated into Campylaspis by Jones (1974). Sars (1900), even though only the genera Campylaspis, Cumella, and Nannastacus were well known at the time (he questioned the validity of Bonnier's Procampylaspis), recognized that Campylaspis was different from the others, especially with regard to its "oral parts," and on that basis created the family Campylaspidae. The possibility of resurrecting the family Campylaspidae as distinct from the remaining Nannastacidae will be discussed in a following paper.

\section{ACKNOWLEDGEMENTS}

I thank Miranda Lowe and Geoffrey Boxshall of The Natural History Museum, London, for the loan of specimens and use of the museum facilities. This paper is NSF/PEET Cumacea Project No. 1.

\section{LiTERATURE CITED}

Băcescu, M., and Z. Muradian. 1974. Campylaspenis, Styloptocuma, Atlantocuma, new genera of Cumacea from the deep waters of the Atlantic.-Revue Roumaine de Biologie, série de Zoologie 19: 71-79.

_ , and —. 1977. Cubanocuma gutzui gen. et sp. n. (Cumacea, Nannastacidae) from the tropical western Atlantic.-Revue Roumaine de Biologie, série Biologie Animale 22: 3-9.

Bonnier, J. 1896. Résultats scientifiques de la Campagne du 'Caudan' dans la Golfe de Gascogne: Cumacea.Annales de l'Université de Lyon 24: 528-562.

Fage, L. 1929. Cumacés et Leptostracés provenant des Campagnes scientifiques de Prince Albert Ier de Monaco.-Résultats des Campagnes Scientifiques de Prince Albert I 77: 1-50.

Jones, N. S. 1984. The Family Nannastacidae (Crustacea: Cumacea) from the deep Atlantic.-Bulletin of the British Museum (Natural History), Zoology, 46: 207-289.

Lomakina, N. B. 1955. Kumovye raki (Cumacea) dal'nyevostochnykh moryakh.-Trudy Zoologicheskogo Instituta Akademia Nauka S.S.S.R. 18: 112-165. [In Russian.]

Norman, A. M. 1879. Crustacea Cumacea of the 'Lightning,' 'Porcupine,' and 'Valorous' expeditions.-Annals and Magazine of Natural History (5) 3: 54-73.

Sars, G. O. 1865. Om dem aberrante krebsdygruppe Cumacea og den nordiske arter.-Förhandlingar i Videnskabs-Selskabet i Christiania 1864: 128-208.

. 1887. Report on the Cumacea collected by the H.M.S. Challenger during the years 1873-76.-Report on the Scientific Results of the Voyage of the H.M.S. Challenger, Zoology, 19 (55): 1-73.

1900. Cumacea.-An account of the Crustacea of Norway with short descriptions and figures of all the species 3: 1-115. Bergen Museum, Bergen, Norway.

Stebbing, T. R. R. 1913. Cumacea (Sympoda).-Das Tierreich 39: 1-210.

Watling, L. 1991. Rediagnosis and revision of some Nannastacidae (Crustacea: Cumacea).-Proceedings of the Biological Society of Washington 104: 751-757.

RECEIVED: 2 May 1997.

ACCEPTED: 11 August 1997.

Address: Darling Marine Center, School of Marine Sciences, University of Maine, Walpole, ME 04573, U.S.A. (e-mail: watling@maine.maine.edu) 